\title{
DO NORMATIVE JUDGEMENTS AIM TO REPRESENT THE WORLD?
}

\author{
Bart Streumer \\ b.streumer@rug.nl \\ Ratio 26 (2013): 450-470 \\ Also in Bart Streumer (ed.), Irrealism in Ethics \\ Published version available here: \\ http://dx.doi.org/10.1111/rati.12035
}

Abstract:

Many philosophers think that normative judgements do not aim to represent the world. In this paper, I argue that this view is incompatible with the thought that when two people make conflicting normative judgements, at most one of these judgements is correct. I argue that this shows that normative judgements do aim to represent the world. 


\section{DO NORMATIVE JUDGEMENTS AIM TO REPRESENT THE WORLD?}

Many philosophers think that normative judgements do not aim to represent the world. In this paper, I shall argue that this view is incompatible with the thought that

(A) When two people make conflicting normative judgements, at most one of these judgements is correct.

I shall argue that this shows that normative judgements do aim to represent the world.

This paper consists of six sections. In section 1, I distinguish cognitivism from noncognitivism. In section 2, I explain why non-cognitivists need to show that their view is compatible with (A). In section 3 , I argue that three simple attempts to show this fail. In sections 4 and 5, I argue that two sophisticated attempts to show this also fail. In section 6, I compare non-cognitivism to an irrealist version of cognitivism: the error theory, which is compatible with (A). I argue that this comparison shows that normative judgements do aim to represent the world.

\section{Cognitivism, non-cognitivism and minimalism}

Cognitivists think that normative judgements are beliefs that ascribe normative properties. ${ }^{1}$ Non-cognitivists think that normative judgements are non-cognitive attitudes, such as attitudes of approval or disapproval. But many non-cognitivists also think that normative judgements are beliefs that ascribe normative properties. For they accept minimalism about truth, beliefs and properties: they think that the sentence " $p$ ' is true" expresses the same

\footnotetext{
${ }^{1}$ I take a property to be normative if and only if it can be ascribed with a normative predicate. This claim need not be regarded as a definition (see Streumer 2013b, p. 311).
} 
attitude as the sentence " $p$ ", that a sentence expresses a belief if and only if it can be true, and that an object has a property if and only if this property can be ascribed to it with a true sentence. ${ }^{2}$

For example, consider the judgement that euthanasia is wrong. If non-cognitivism is true, this judgement is a non-cognitive attitude, such as an attitude of disapproval of euthanasia. Non-cognitivists who accept minimalism think that this attitude can be expressed not only with the sentence

\section{Euthanasia is wrong,}

but also with the sentence

"Euthanasia is wrong" is true.

They therefore think that the judgement that euthanasia is wrong is not only an attitude of disapproval, but also a belief. And if they disapprove of euthanasia themselves, they think that euthanasia has the property of being wrong. For this property can be ascribed to it with the sentence "Euthanasia is wrong", which they think is true.

There are now two possibilities. The first is that non-cognitivists agree with cognitivists that normative judgements are beliefs that ascribe normative properties in $a$ single sense of the terms 'belief' and 'property'. I then do not need to write the rest of this paper, since non-cognitivists agree with everything that cognitivists say. The second possibility is that non-cognitivists agree with cognitivists that normative judgements are beliefs that ascribe normative properties, but not in the same sense of the terms 'belief' and 'property'. I then do need to write the rest of this paper, since the apparent agreement

\footnotetext{
${ }^{2}$ Horwich 1993 proposes a minimalist account of the truth of normative judgements, and Blackburn 1998, pp. 77-83, and Gibbard 2003, p. 18, endorse such an account (though not in the way Horwich proposes). For discussion of the relation between non-cognitivism and minimalism about truth, see Jackson, Oppy and Smith 1994, Smith 1994b and 1994c, Divers and Miller 1994 and 1995, and Dreier 1996 and 2004.
} 
between cognitivists and non-cognitivists masks a deeper disagreement. That is what I shall assume to be the case.

To make this disagreement explicit, I shall take cognitivism to be the following view:

Normative judgements aim to represent the world. Whether these judgements succeed at representing the world wholly depends on what the world is like: it depends on whether objects in the world have the normative properties that these judgements ascribe to them.

And I shall take non-cognitivism to be the following view:

Normative judgements do not aim to represent the world. These judgements ascribe normative properties to objects in the world, but whether these objects have these properties does not wholly depend on what the world is like. ${ }^{3}$

Everyone agrees that if a normative judgement ascribes a descriptive property, part of this judgement aims to represent the world. ${ }^{4}$ For example, suppose that Susan thinks that Fred's dishonesty is wrong. Susan's normative judgement then ascribes the descriptive property of being dishonest to Fred. This part of her judgement clearly aims to represent the world. But Susan's judgement also ascribes the normative property of being wrong to Fred's dishonesty. I shall take cognitivists and non-cognitivists to disagree about whether this normative part of a normative judgement aims to represent the world. ${ }^{5}$

\footnotetext{
${ }^{3}$ This claim is also made by Horgan and Timmons' cognitivist expressivism, which they take to be a version of cognitivism (see Horgan and Timmons 2006a and 2006b, and also Timmons 1999 and Horgan and Timmons 2000). I take this view to be a version of non-cognitivism. It would perhaps be clearer to call cognitivism 'representationalism' and non-cognitivism 'non-representationalism', but I shall continue to use these views' familiar names.

${ }^{4}$ I take a property to be descriptive if and only if it can be ascribed with a descriptive predicate. As before, this claim need not be regarded as a definition.

${ }^{5}$ Many philosophers now defend views that combine elements of non-cognitivism with elements of cognitivism: see, for example, Copp 2001, Ridge 2006, 2007 and 2009, and Boisvert 2008. These
} 
Does this make the disagreement between cognitivists and non-cognitivists explicit? You may think not, since non-cognitivists may also be minimalists about representation: they may think that the sentence " $p$ succeeds at representing the world" expresses the same attitude as the sentence " $p$ ", and that a sentence expresses an attitude that aims to represent the world if and only if this sentence can succeed at representing the world. ${ }^{6}$ But if noncognitivists keep retreating to minimalism, they will end up agreeing with everything that cognitivists say. As before, I then do not need to write the rest of this paper. I shall therefore assume that non-cognitivists will not keep retreating to minimalism. Since it forces me to write the rest of this paper, this is a charitable assumption.

\section{Asymmetry}

We normally take conflicts between normative judgements to be asymmetrical: we normally think that

(A) When two people make conflicting normative judgements, at most one of these judgements is correct. ${ }^{7}$

For example, suppose that Fred thinks that euthanasia is always permissible and Susan thinks that it is always impermissible. We may then think that Fred's judgement is correct, or we may think that Susan's judgement is correct, or we may think that neither judgement is correct. But we will not think that both judgements are correct. Euthanasia cannot be both always permissible and always impermissible.

We may not take (A) to be true of normative judgements that differ in imprecise

philosophers think that normative judgements partly aim to represent the world the way cognitivists think they do, but that the properties these judgements ascribe are not irreducibly normative. I do not have space to discuss these views here, but I think they face either the objections to reductive realism I put forward in Streumer 2011 or the argument against non-cognitivism I shall put forward below.

${ }^{6}$ See Dreier 2004, p. 29.

${ }^{7}$ See also Smith 1994a, p. 39. 
ways. If Fred thinks that friendship is quite valuable and Susan thinks that it is very valuable, we may not think that at most one of these judgements is correct. We also may not take (A) to be true of judgements about moral dilemmas. If Sophie cannot save both of her children, and if Fred thinks that she ought to save her daughter and Susan thinks that she ought to save her son, we may not think that at most one of these judgements is correct. But we do think that

(A') When two people make conflicting normative judgements that do not differ in an imprecise way and that are not about a moral dilemma, at most one of these judgements is correct.

Since the difference between (A) and (A') will not affect my arguments, I shall ignore it in what follows.

(A) is what I shall call a central pre-theoretical thought about normative judgements: it is a thought that partly determines what normative judgements are. To see this, consider an analogous claim about likes or dislikes:

(L) When two people have conflicting likes or dislikes, at most one of these likes or dislikes is correct.

We do not take (L) to be true. For example, suppose that Bob likes peanut butter and Kate dislikes it. We may then share Bob's like, or we may share Kate's dislike, or we may share neither like or dislike. But we will not think that at most one of these likes or dislikes is correct. That we take (A) to be true of normative judgements but do not take (L) to be true of likes or dislikes is part of what distinguishes normative judgements from likes or dislikes. This means that (A) partly determines what normative judgements are. If a theory about normative judgements is incompatible with (A), therefore, it partly changes the subject. This can be legitimate, but only if there is no defensible theory about normative judgements that is compatible with all of our central pre-theoretical thoughts about them.

Cognitivism is clearly compatible with (A). If normative judgements aim to represent the world, conflicting normative judgements aim to represent the world in incompatible ways. Since the world cannot be both of these ways, these judgements cannot both be correct. For example, if cognitivism is true, Fred's judgement ascribes the property of being always 
permissible to euthanasia and Susan's judgement ascribes the property of being always impermissible to euthanasia. Since euthanasia cannot have both of these properties, Fred and Susan's judgements cannot both be correct.

Is non-cognitivism also compatible with (A)? This is less clear. Since non-cognitivists deny that normative judgements aim to represent the world, they cannot show that their view is compatible with (A) by saying that conflicting normative judgements aim to represent the world in incompatible ways. They need to show in a different way that their view is compatible with (A). In the next four sections, I shall discuss five ways in which noncognitivists could try to show this. I shall argue that they all fail.

\section{Three simple attempts}

Non-cognitivists may think that there is a simple way to show that their view is compatible with (A). First, they could say that their view is compatible with (A) because thinking that a normative judgement is correct is the same thing as making this judgement yourself. ${ }^{8}$ For example, suppose again that Fred thinks that euthanasia is always permissible, and suppose that I think that Fred's judgement is correct. Non-cognitivists could say that my thinking that Fred's judgement is correct is the same thing as my making the judgement that euthanasia is always permissible myself. But when two people make conflicting normative judgements, I can think that at most one of these judgements is correct without having a view about which of these judgements is correct. For example, I can think that at most one of Fred and Susan's judgements about euthanasia is correct without thinking that Fred's judgement is correct and without thinking that Susan's judgement is correct. Even if thinking that a normative judgement is correct is the same thing as making this judgement yourself, therefore, that does not show that non-cognitivism is compatible with (A). ${ }^{9}$

Second, non-cognitivists could say that their view is compatible with (A) because a

\footnotetext{
${ }^{8}$ This is suggested by Blackburn's remarks about 'Ramsey's ladder' (Blackburn 1998, pp. 78, 295 6).

${ }^{9}$ Non-cognitivists may try to improve this attempt by adding that we disapprove of both approving and disapproving of a single thing. I shall return to this claim in $\S 4$.
} 
normative judgement is incorrect if it is based on a false descriptive belief. ${ }^{10}$ For example, suppose that Fred's judgement that euthanasia is always permissible is based on his false descriptive belief that euthanasia does not involve killing a human being. In that case, noncognitivists could say, Fred's judgement is incorrect. But when two people make conflicting normative judgements, neither of them may base his or her judgement on a false descriptive belief. For example, Fred may base his judgement that euthanasia is always permissible on his true descriptive belief that allowing people to have euthanasia minimises their suffering, and Susan may base her judgement that euthanasia is always impermissible on her true descriptive belief that euthanasia involves killing a human being. But we nevertheless think that at most one of these judgements is correct. Even if a normative judgement is incorrect if it is based on a false descriptive belief, therefore, that does not show that non-cognitivism is compatible with (A) either.

Third, non-cognitivists could say that their view is compatible with (A) because normative judgements can be made correct or incorrect by descriptive facts. ${ }^{11}$ For example, we may think that the descriptive fact that allowing people to have euthanasia minimises their suffering makes Fred's judgement correct and Susan's judgement incorrect. If cognitivism is true, the thought that a certain fact makes a certain normative judgement correct or incorrect need not itself be further normative judgement, but may simply be the thought that this judgement succeeds or fails at representing this fact. But if non-cognitivism is true, the thought that a certain fact makes a certain normative judgement correct or incorrect must itself be a further normative judgement. ${ }^{12}$ This further normative judgement can conflict with other normative judgements: for example, Susan may think that the descriptive fact that allowing people to have euthanasia minimises their suffering does not make Fred's judgement correct and her own judgement incorrect. And (A) will only be true of Fred and

\footnotetext{
${ }^{10}$ This is suggested by Ayer's claims about moral disagreement (1946, pp. 21-2, 110-2). I take a descriptive belief to be a belief about a descriptive fact, and I take a descriptive fact to be a fact that does not involve the instantiation of a normative property.

${ }^{11}$ This is suggested by Horgan and Timmons' remarks about the grounds of normative judgements (2006a, pp. 265, 268, 272).

${ }^{12}$ As Horgan and Timmons recognise (2006a, p. 286). See also Stevenson 1963, pp. 87-9.
} 
Susan's initial normative judgements if it is also true of these further normative judgements. This is clearly the start of a regress. Even if normative judgements can be made correct or incorrect by descriptive facts, therefore, that does not show that non-cognitivism is compatible with (A) either.

These three simple attempts to show that non-cognitivism is compatible with (A) therefore fail. Non-cognitivists need to show in a more sophisticated way that their view is compatible with (A).

\section{A quasi-realist attempt}

They could next try to show that their view is compatible with (A) by making use of Simon Blackburn's work. Consider the following claim:

(M) What makes an action right or wrong is not that we approve or disapprove of this action.

We may think that non-cognitivism is incompatible with (M). If normative judgements are attitudes of approval or disapproval, we may think, these attitudes are the only things that can make an action right or wrong. But Blackburn disagrees. He claims that (M) expresses the following attitude:

$\left(M^{*}\right)$ Disapproval of treating our own attitudes of approval or disapproval as grounds for approving or disapproving of an action. ${ }^{13}$

\footnotetext{
${ }^{13}$ Blackburn 1984, p. 218, 1993, pp. 153, 157, 172-3, and 1998, p. 311-2. Blackburn occasionally claims that moral judgements are attitudes of approval or disapproval (1984, p. 192), but he often simply says that they are 'attitudes' $(1984$, pp. 167, 188) or 'conative' states or stances (1993, pp. 168, 178). He rightly notes that "approval and attitude are natural terms to work with, but it would not matter if neither fitted exactly or if better terms for the state in question existed", as long as "the state is worth distinguishing from belief, or at least from belief with representational truth conditions thought of realistically" (1993, p. 184).
} 
If it expresses this attitude of disapproval, (M) is compatible with non-cognitivism.

Blackburn also argues that sentences that contain unasserted normative clauses express attitudes of approval or disapproval, that we can regard changes in our own attitudes of approval or disapproval as improvements, and that the truth of a normative judgement is its membership of a set of attitudes of approval or disapproval that cannot be further improved. ${ }^{14}$ In this way, he thinks, non-cognitivists 'earn the right' to say that normative judgements are beliefs that ascribe normative properties and that can be true, especially if they also endorse minimalism about beliefs, properties and truth. ${ }^{15}$ They then stop being non-cognitivists and become what Blackburn calls quasi-realists. ${ }^{16}$

Non-cognitivists could try to show that their view is compatible with (A) in a similar way. They could say that (A) expresses an attitude of approval or disapproval, such as:

(A*) Disapproval of both approving and disapproving of a single thing. ${ }^{17}$

\footnotetext{
${ }^{14}$ For Blackburn's interpretations of claims that contain unasserted normative clauses as attitudes of approval or disapproval, see Blackburn 1984, pp. 189-96, 1993, pp. 125-7, 182-97, and 1998, pp. 70-77. Blackburn 1993, pp. 182-97, proposes an interpretation of such claims as expressions of attitudes of approval or toleration. For Blackburn's account of the truth of normative judgements as membership of a set of attitudes of approval or disapproval that cannot be further improved, see Blackburn 1984, pp. 197-202. Blackburn does not wholeheartedly endorse this account, however, and Blackburn 1998 appeals more directly to minimalism about truth.

${ }^{15}$ Blackburn 1998, pp. 77-83, 294-8. He stresses that, before non-cognitivists can make use of minimalism in this way, "the commitments must first be understood in other terms" (1998, p. 80). See also Blackburn 1996, pp. 86, 92, and 1999, p. 217.

${ }^{16}$ See Blackburn 1984, 1993 and 1998. For his denial that quasi-realism is a version of noncognitivism, see Blackburn 1996, pp. 82-3, and 1998, p. 85. In his later work, Blackburn calls both non-cognitivism and quasi-realism 'expressivism'. As Lenman 2003 notes, quasi-realism "is more or less synonymous with Simon Blackburn" (p. 34 n. 7), but Allan Gibbard endorses it as well (2003 pp. 18-9, 112), and many non-cognitivists have considerable sympathy for it.

${ }^{17}$ Though Blackburn does not discuss (A), he does discuss bivalence (1984, pp. 203-10, and 1993 , pp. 23-30), and his discussion of bivalence suggests an interpretation of (A) as expressing the attitude described by $\left(\mathrm{A}^{*}\right)$. Alternatively, Blackburn could also interpret the claim that one of two particular conflicting normative judgements is correct as expressing a particular attitude of approval or disapproval in an emphatic way, and he could then interpret (A) as a generalization of such emphatic expressions of particular attitudes of approval or disapproval. But it is difficult to see how (A) can be
} 
For example, suppose again that Fred thinks that euthanasia is always permissible and Susan thinks that it is always impermissible. And suppose that Fred and Susan both take (A) to be true: they both think that at most one of these judgements is correct. If normative judgements are attitudes of approval or disapproval and (A) expresses the attitude described by (A*), Fred then has the following attitudes:

Approval of allowing people to have euthanasia, and disapproval of both approving and disapproving of allowing people to have euthanasia.

And Susan has the following attitudes:

Disapproval of allowing people to have euthanasia, and disapproval of both approving and disapproving of allowing people to have euthanasia. ${ }^{18}$

If (A) expresses the attitude described by $\left(\mathrm{A}^{*}\right)$ and we all have this attitude, non-cognitivists could therefore say, their view is compatible with (A).

But I think that this does not follow. To see this, we can again compare the conflict between Fred and Susan's normative judgements to the conflict between Bob's like and Kate's dislike of peanut butter. As I have said, we do not think that

(L) When two people have conflicting likes or dislikes, at most one of these likes or dislikes is correct.

But suppose that Bob and Kate do take (L) to be true: they both think that at most one of their

a generalization of such emphatic expressions, since as I pointed out in $\S 3$ we can think that (A) is true without thinking that any particular normative judgement is correct.

${ }^{18}$ I take the judgement that euthanasia is always permissible to be equivalent to the judgement that it is right to allow people to have euthanasia, and the judgement that euthanasia is always impermissible to be equivalent to the judgement that it is wrong to allow people to have euthanasia. I take 'allowing people to have euthanasia' to mean not stopping people from having euthanasia. 
conflicting likes or dislikes is correct. And suppose that a philosopher then says that (L) expresses the following attitude:

(L*) A dislike of both liking and disliking a single thing.

If (L) expressed this dislike, Bob would have the following like and dislike:

A like of peanut butter and a dislike of both liking and disliking peanut butter.

And Kate would have the following dislikes:

A dislike of peanut butter and a dislike of both liking and disliking peanut butter.

But that clearly would not mean that (L) is true: it would not mean that it really is the case that at most one of Bob and Kate's likes or dislikes is correct. Instead, it would merely mean that Bob and Kate have a shared higher-order dislike. In the same way, if Fred and Susan both have the attitude described by $\left(\mathrm{A}^{*}\right)$, that does not mean that $(\mathrm{A})$ is true: it does not mean that it really is the case that at most one of Fred and Susan's attitudes of approval or disapproval is correct. Instead, it merely means that Fred and Susan have a shared higherorder attitude of disapproval. Even if we all had this attitude of disapproval, therefore, that would not show that non-cognitivism is compatible with (A).

Non-cognitivists could reply that what matters is not whether Fred and Susan have the attitude described by $\left(\mathrm{A}^{*}\right)$ or whether Bob and Kate have the dislike described by $\left(\mathrm{L}^{*}\right)$, but whether we have this attitude or this dislike. But that misunderstands the point of the comparison between (A) and (L). What this comparison shows is that there is a difference between a someone's having the attitude described by $\left(\mathrm{A}^{*}\right)$ or the dislike described by $\left(\mathrm{L}^{*}\right)$ on the one hand, and (A) or (L) really being true on the other hand. Since Bob and Kate's having the dislike described by $\left(\mathrm{L}^{*}\right)$ does not mean that $(\mathrm{L})$ is really true, our having this dislike would not mean that (L) is really true either. Similarly, since Fred and Susan's having the attitude of disapproval described by $\left(\mathrm{A}^{*}\right)$ does not mean that $(\mathrm{A})$ is really true, our having this attitude of disapproval does not mean that $(\mathrm{A})$ is really true either.

Non-cognitivists may think that this is confused. If (A) expresses the attitude of 
disapproval described by $\left(\mathrm{A}^{*}\right)$, they may say, our having the attitude described by $\left(\mathrm{A}^{*}\right)$ is what it is for (A) to be true. ${ }^{19}$ If we have this attitude, they may therefore say, this does mean that (A) is really true. But that misrepresents what is at issue. What is at issue is not whether it is true that

(1) If (A) expresses the attitude of disapproval described by (A*) and we all have this attitude, (A) is really true.

Instead, what is at issue is whether it is true that

(2) If we all have the attitude of disapproval described by $\left(\mathrm{A}^{*}\right),(\mathrm{A})$ is really true.

I agree that (1) is true: if (A) expresses the attitude of disapproval described by $\left(\mathrm{A}^{*}\right)$ and we all have this attitude, then (A) is true. But I deny the first conjunct of the antecedent of (1): I deny that (A) expresses the attitude of disapproval described by (A*). I deny this because I think that (2) is false: I think that if we all have the attitude of disapproval described by $\left(\mathrm{A}^{*}\right)$, this does not mean that $(\mathrm{A})$ is really true. I take this to be shown by the fact that if Bob and Kate have the dislike described by $\left(\mathrm{L}^{*}\right)$, that similarly does not mean that $(\mathrm{L})$ is really true.

Non-cognitivists could reply that they themselves do think that (2) is true: they think that if we have the attitude of disapproval described by (A*), (A) is really true. But I think that this would betray what Goldman and Pust call 'theory contamination' ${ }^{20}$ Non-cognitivists clearly do not accept (2) because it is pre-theoretically attractive to interpret (A) as expressing an attitude of disapproval. Instead, they accept (2) because they accept non-cognitivism for other reasons, and because, in order to defend non-cognitivism, they need to show that this view is compatible with (A). In other words, they accept (2) because their philosophical theory has contaminated their understanding of (A). It can be legitimate to revise a central pre-theoretical thought about something in order to accept a philosophical theory about this

\footnotetext{
${ }^{19}$ To reinforce this point, they may appeal to minimalism: they may say that the sentence "(A) is true" expresses the same attitude as the sentence "(A)".

${ }^{20}$ See Goldman and Pust 1998, pp. 183, 189.
} 
thing, but only if there is no defensible theory about this thing that is compatible with all of our central pre-theoretical thoughts about it. I shall argue in $\S 7$ that there is such a theory: the error theory, according to which normative judgements are beliefs that ascribe normative properties even though these properties do not exist. If that is so, it is not legitimate for noncognitivists to revise our pre-theoretical understanding of (A) in order to accept (2).

Non-cognitivists may accuse me of being a victim of theory contamination myself: they may say that I reject (2) merely because I believe the error theory for other reasons, and because, in order to defend the error theory, I need to reject non-cognitivism. But I have argued elsewhere that we cannot believe the error theory, and 'we' includes me. ${ }^{21} \mathrm{My}$ rejection of (2) therefore does not result from a belief in the error theory. Non-cognitivists could reply that I do accept cognitivism, and that this is the source of the contamination. But as I have explained elsewhere, I do not stably accept cognitivism either: when I consider the strongest arguments against the existence of normative properties, I am inclined to accept non-cognitivism instead. ${ }^{22}$ My rejection of (2) therefore does not result from a stable acceptance of either the error theory or cognitivism. Instead, it results from my holding on to one of our central pre-theoretical thoughts about normative judgements.

It is worth noting that Blackburn does not offer any evidence to show that claims like (M) or (A) actually do express attitudes of approval or disapproval. All he shows is that it is possible to interpret such claims in this way. But merely showing that it is possible to interpret claims like (M) or (A) as expressions of attitudes of approval or disapproval is not enough to show that it is correct to interpret these claims in this way. I take the comparison between (A) and (L) to show that it is not correct to interpret (A) in this way.

As a last resort, non-cognitivists could now repeat Blackburn's quasi-realist move. They could say that my claim that

(3) (A) does not express the attitude described by (A*)

\footnotetext{
${ }^{21}$ Streumer 2013a.

${ }^{22}$ Streumer 2013a, p. 203.
} 
itself expresses an attitude of approval or disapproval, such as:

$\left(3^{*}\right) \quad$ Disapproval of believing that $(\mathrm{A})$ expresses the attitude described by $\left(\mathrm{A}^{*}\right)$.

But if non-cognitivists said this, my argument would simply repeat itself. Just as I deny that (2) is true, I also deny that

(4) If we have the attitudes of disapproval described by (A*) and (3*), (A) and (3) are really true.

For just as the comparison between (A) and (L) shows that our having the attitude described by $\left(\mathrm{A}^{*}\right)$ does not mean that $(\mathrm{A})$ is really true, it also shows that our having the attitude described by $\left(3^{*}\right)$ does not mean that (3) is really true.

I therefore think that non-cognitivists cannot make use of Blackburn's quasi-realism to show that their view is compatible with (A). They need to show this in a different way.

\section{A plan-expressivist attempt}

Non-cognitivists could next try to show that their view is compatible with (A) by appealing to an argument that has been given by Allan Gibbard. According to Gibbard's planexpressivism, to think that you ought to do something is to adopt a plan. ${ }^{23}$ Adopting a plan involves rejecting certain alternatives, which Gibbard calls 'not okay to do', and rejecting rejecting other alternatives, which he calls 'okay to do'.

Like Blackburn, Gibbard interprets (M) and sentences that contain unasserted

\footnotetext{
${ }^{23}$ See Gibbard 2003 (though Gibbard does not call his view 'plan-expressivism'). Unlike Blackburn, Gibbard accepts that, "in one sense", his view is non-cognitivist (2003 p. 184; see also Gibbard 1990, p. 8). He first offers a "possibility proof" to show that there can be judgements of adopting a plan that behave very much like normative judgements, and he proposes the hypothesis that normative judgements "have much to do with" these judgements of adopting a plan (see pp. 20, $138-9,179)$.
} 
normative clauses as expressions of non-cognitive attitudes, in his case the adoption of plans. ${ }^{24}$ But he also gives an argument to show that all planners are committed to the claim that

(P) There is a natural property that constitutes being okay to do. ${ }^{25}$

Non-cognitivists could try to use this argument to show that their view is compatible with (A). For if there is natural property that constitutes being okay to do, they may think, a normative judgement is correct if and only if the object to which it ascribes this property really has this property.

Gibbard's argument can be presented as follows. ${ }^{26}$ Call a consistent plan that covers any situation that anyone could ever be in a 'hyperplan' ${ }^{27}$ Since planners must identify acts in terms of their natural properties, Gibbard thinks, a hyperplan must have the following form:

In situation $s_{1}$, perform an act with natural property $\mathrm{N}_{1}$, in situation $s_{2}$, perform an act with natural property $\mathrm{N}_{2}, \ldots$

Consider next the property of having either natural property $\mathrm{N}_{1}$, or natural property $\mathrm{N}_{2}, \ldots$ Call this property ' $\mathrm{N}^{*}$ '. Any hyperplan can then be reformulated as follows:

In any possible situation, perform an act with natural property $\mathrm{N}^{*}$.

\footnotetext{
${ }^{24}$ See Gibbard 2003, p. 183, and 1990, pp. 164-6.

${ }^{25}$ Gibbard 2003, pp. 95-6. What Gibbard means by 'constitutes' is that for any alternative $a$ open in any possible situation $s$, alternative $a$ is okay to do in $s$ just in case $a$ in $s$ has property N. He initially calls property $\mathrm{N}$ a "prosaically factual" property, but he later argues that it is, in a broad sense, a natural property (pp. 98-102).

${ }^{26}$ See Gibbard 2003, pp. 88-111. See also Gibbard 2002a, 2002b, and 2006. For discussion of this argument, see Hawthorne 2002 and Majors 2005.

${ }^{27}$ Gibbard 2003, p. 56.
} 
Gibbard takes this to show that anyone who adopts a hyperplan accepts that there is a natural property $\mathrm{N}^{*}$ that constitutes being okay to do. This means that anyone who adopts a hyperplan accepts $(\mathrm{P})$.

Call a state of both having adopted a hyperplan and having a complete and consistent set of descriptive beliefs a 'hyperstate'. ${ }^{28}$ And call a planner 'committed' to a claim if he would accept this claim in every hyperstate he could reach from his present plans and descriptive beliefs without changing his mind. ${ }^{29}$ If anyone who adopts a hyperplan accepts $(\mathrm{P})$, all planners would accept $(\mathrm{P})$ in every hyperstate they could reach without changing their minds. According to Gibbard, this shows that all planners are committed to (P).

But does it also show that non-cognitivism is compatible with (A)? I think not. Suppose again that Fred thinks that euthanasia is always permissible and Susan thinks that it is always impermissible. If plan-expressivism is true, Fred has then adopted the following plan:

To always allow people to have euthanasia.

And Susan has adopted the following plan:

To never allow people to have euthanasia.

Since these are conflicting plans, the hyperplans Fred and Susan can reach from these plans are conflicting hyperplans, according to which different natural properties constitute being okay to do. This means that even if Gibbard is right that Fred and Susan are both committed to the claim that there is a natural property that constitutes being okay to do, they are committed to different claims about which natural property constitutes being okay to do. And if plan-expressivism is true, which natural property constitutes being okay to do does not

\footnotetext{
${ }^{28}$ Gibbard 2003, pp. 54, 90. Gibbard actually says that someone who is in a hyperstate "suspends no belief on matters of prosaic fact" (p. 90), and he intends the term 'prosaic' to exclude any facts about what to do, if there are such facts.

${ }^{29}$ Gibbard 2003, p. 91.
} 
depend on the world, but on the hyperplans that Fred and Susan can reach from the plans they have adopted. Showing that they are both committed to $(\mathrm{P})$ therefore does not show that at most one of their conflicting normative judgements is correct. ${ }^{30}$

Non-cognitivists could reply that the question which natural property constitutes the property of being okay to do is itself a question about what to do, which can only be answered by adopting further a plan. ${ }^{31}$ But (A) will only be true of Fred and Susan's initial plans if it is also true of this further plan. This reply therefore faces the same problem as the third attempt to show that non-cognitivism is compatible with (A) that I discussed in $\S 3$.

I therefore think that non-cognitivists cannot appeal to Gibbard's argument to show that their view is compatible with (A) either. And I am not aware of any other way in which non-cognitivists could try to show this. I therefore think that non-cognitivism is incompatible with (A). ${ }^{32}$

${ }^{30}$ A similar objection to Gibbard's view is made by Schroeter and Schroeter 2005, who argue that Gibbard's view guarantees neither that all competent speakers use a given normative predicate to ascribe the same natural property (which they call 'univocity'), nor that there is an independent standard of correctness for normative judgements to which speakers are answerable (which they call 'objectivity').

${ }^{31}$ As Gibbard 2002b writes: "Come to a full plan for life, and you will have come to a view on what property constitutes the thing to do. Will you have the answer right? . . [T] hat again is a question about how to live. It can be answered only in plan-laden terms" (p. 179).

${ }^{32}$ Non-cognitivists do sometimes suggest that people's pre-theoretical thoughts about normative judgements are mistaken. For example, Blackburn says that quasi-realism's "explanation of why there are obligations and all the rest is not quite that of untutored common sense" (1993, p. 157; see also pp. 150-1). And he says that, if quasi-realists 'earn the right' to say everything realists say, "you cannot rely upon first thoughts, or immediate armchair reactions, or your unprocessed knowledge of what you mean by some commitments, to determine whether the theory is true" (1984, p. 210). Similarly, when considering the "Platonistic" view that ordinary judgements about rationality are beliefs about non-natural facts, Gibbard 1990 says that "[i]f this is what anyone seriously believes, then I simply want to debunk it" (p. 154), though he also says that this is not a strong strain in ordinary thought. Ridge 2009 also says that, since we normally seem to think that normative sentences express beliefs, his version of expressivism implies "that our understanding of ourselves is in an important way mistaken" (p. 230). 


\section{Non-cognitivism and the error theory}

Does this show that non-cognitivism is false? That depends on whether there is a defensible alternative to non-cognitivism that is compatible with (A) and with our other pre-theoretical thoughts about normative judgements. As I said in $\S 4$, I think there is such an alternative: the error theory, according to which normative judgements are beliefs that ascribe normative properties even though these properties do not exist. Like non-cognitivism, the error theory is a version of irrealism, since it denies that there are normative properties in the sense of real features of things in the world. But it is a cognitivist version of irrealism, since it says that normative judgements do aim to represent such features.

When non-cognitivists attack cognitivism, they often ignore the error theory. Consider again Blackburn's interpretation of the claim that

(M) What makes an action right or wrong is not that we approve or disapprove of this action.

Calling his own interpretation of $(\mathrm{M})$ the 'internal' reading and the cognitivist interpretation of $(\mathrm{M})$ the 'external' reading, Blackburn writes:

There would be an external reading if realism were true. For in that case there would be a fact, a state of affairs ... whose rise and fall and dependency on others could be charted. But anti-realism acknowledges no such state of affairs and no such dependency. ${ }^{33}$

This ignores the fact that error theorists, who agree that there is no such state of affairs, can endorse the external reading of (M). Rejecting realism is therefore not enough to refute the external reading of $(\mathrm{M})$. But in the argument that Blackburn elsewhere gives against the error

\footnotetext{
${ }^{33}$ Blackburn 1993, p. 173.
} 
theory, he takes his own internal reading of claims like (M) for granted. ${ }^{34}$

I have elsewhere argued that there are no normative properties, at least not in the sense of real features of things in the world. ${ }^{35}$ Since non-cognitivism and the error theory are both versions of irrealism, they are both compatible with this conclusion. But unlike noncognitivism, the error theory is also compatible with (A). Non-cognitivists may deny this: they may say that if the error theory is true, all normative judgements are false, which means that all normative judgements are incorrect. But (A) does not say that

When two people make conflicting normative judgements, one of these judgements is correct.

Instead, what (A) says is that

When two people make conflicting normative judgements, at most one of these judgements is correct.

I think that $(\mathrm{A})$ is made true by the nature of normative judgements: it is made true by the nature of normative judgements being such that when two of these judgements conflict, at most one of them is correct. (A) does not say or imply that the world is such that when two normative judgements conflict, it actually makes one of these judgements correct. Unlike non-cognitivism, therefore, the error theory is compatible with (A).

Non-cognitivists could reply that in addition to thinking that (A) is true, we also think that

(C) Some normative judgements are correct.

Since the error theory implies that all normative judgements are false, non-cognitivists could

\footnotetext{
${ }^{34}$ Blackburn 1993, p. 153

${ }^{35}$ See Streumer 2008, 2011 and 2013b.
} 
say, it implies that all normative judgements are incorrect. If incompatibility with our pretheoretical thoughts is fatal to a philosophical view, they could therefore say, this is just as fatal to the error theory as it is to non-cognitivism.

But I think there is an important difference between (A) and (C). As I said in $\S 2,(A)$ is a central pre-theoretical thought about normative judgements, in the sense that it partly determines what normative judgements are. A theory about normative judgements that is incompatible with (A) therefore partly changes the subject. (C) is clearly also a pretheoretical thought about normative judgements. But if an attitude aims to represent the world, our pre-theoretical thoughts about this attitude cannot guarantee that this attitude is correct, since these thoughts cannot guarantee that the world is as this attitude represents it to be. This means that, unlike (A), (C) is not a central pre-theoretical thought about normative judgements, in the sense that (C) does not partly determine what normative judgements are. A theory about normative judgements that is incompatible with $(\mathrm{C})$ therefore does not change the subject.

Non-cognitivists could also say that charitable interpretation supports their view rather than the error theory, since charitable interpretation requires that we interpret others' claims in such a way that most of these claims turn out to be true. But charitable interpretation does not in fact require this. ${ }^{36}$ For example, charitable interpretation of religious believers' claims about God does not require that we interpret these claims in such a way that most of these claims turn out to be true. Charitable interpretation therefore does not support non-cognitivism.

Finally, non-cognitivists may say that that the connection between normative judgements and motivation supports their view rather than the error theory, since this connection shows that normative judgements are motivating states rather than attitudes that aim to represent the world. But many normative judgements, such as epistemic judgements or judgements about theoretical rationality, are not closely connected to motivation at all. And though there is probably a defeasible global connection between making moral judgements and motivation, it is clearly possible to make an individual moral judgement without being

\footnotetext{
${ }^{36}$ See Cuneo 2006, pp. 59-60.
} 
motivated to act in accordance with this judgement. This weak connection between moral judgements and motivation therefore does not support non-cognitivism either.

I therefore think that the error theory is a defensible alternative to non-cognitivism that is compatible with both (A) and our other pre-theoretical thoughts about normative judgements. Since the error theory is a version of cognitivism, this means that cognitivism is true.

\section{Conclusion}

I conclude that, contrary to what non-cognitivists think, normative judgements aim to represent the world. Of course, that does not mean that these judgements ever succeed at representing the world. But if we believe that normative judgements aim to represent the world, we may be unable to believe that none of them succeed. ${ }^{37}$

\section{References}

Ayer, A. J. 1946. Language, Truth and Logic (second edition). London: Gollancz.

Blackburn, Simon. 1984. Spreading the Word. Oxford: Clarendon Press.

Blackburn, Simon. 1993. Essays in Quasi-Realism. Oxford: Oxford University Press.

Blackburn, Simon. 1996. "Securing the Nots". In Walter Sinnott-Armstrong and Mark Timmons, eds., Moral Knowledge? New Readings in Moral Epistemology. Oxford: Oxford University Press.

\footnotetext{
${ }^{37}$ See Streumer 2013a. For helpful comments on several different precursors to this paper, I am grateful to audiences at the Open University, the University of Sheffield, the Eighth Metaethics Workshop at the University of Wisconsin, Madison, and the Third Annual Dutch Conference on Practical Philosophy at the University of Amsterdam, to the participants in my Spring 2013 graduate class at the University of Reading, and to Tim Chappell, Terence Cuneo, Guy Fletcher, Jimmy Lenman, Don Loeb, Jonas Olson, Tristram McPherson, Carolyn Price, Mark Schroeder, Nishi Shah, Robert Stern, Philip Stratton-Lake, and Jussi Suikkanen.
} 
Blackburn, Simon. 1998. Ruling Passions. Oxford: Clarendon Press.

Blackburn, Simon. 1999. “Is Objective Moral Justification Possible on a Quasi-Realist Foundation?" Inquiry 42: 213-28.

Boisvert, Daniel. 2008. “Expressive-Assertivism”. Pacific Philosophical Quarterly 89: 169203.

Copp, David. 2001. "Realist-Expressivism: A Neglected Option for Moral Realism”. Social Philosophy and Policy 18: 1-43.

Cuneo, Terence. 2006. "Saying What We Mean: An Argument Against Expressivism”. In Russ Shafer-Landau, ed., Oxford Studies in Metaethics, Volume 1. Oxford: Oxford University Press.

Divers, John, and Alexander Miller. 1994. "Why Expressivists about Value Should Not Love Minimalism about Truth". Analysis 54: 12-9.

Divers, John, and Alexander Miller. 1995. "Platitudes and Attitudes: a Minimalist Conception of Belief". Analysis 55: 37-44.

Dreier, James. 1996. "Expressivist Embeddings and Minimalist Truth”. Philosophical Studies 83: 29-51.

Dreier, James. 2004. "Meta-Ethics and the Problem of Creeping Minimalism". Philosophical Perspectives 18: 23-44.

Gibbard, Allan. 1990. Wise Choices, Apt Feelings. Oxford: Clarendon Press.

Gibbard, Allan. 2002a. "Normative and Recognitional Concepts". Philosophy and Phenomenological Research 64: 151-67.

Gibbard, Allan. 2002b. "Reply to Hawthorne". Philosophy and Phenomenological Research 64: 179-83.

Gibbard, Allan. 2003. Thinking How To Live. Cambridge, Mass.: Harvard University Press.

Gibbard, Allan. 2006. "Normative Properties". In Horgan and Timmons, eds., Metaethics after Moore. Oxford: Oxford University Press.

Goldman, Alvin, and Joel Pust. 1998. "Philosophical Theory and Intuitional Evidence”. In Michael DePaul and William Ramsey, eds., Rethinking Intuition. Lanham: Rowman and Littlefield.

Hawthorne, John. 2002. "Practical Realism?" Philosophy and Phenomenological Research 64: 169-78.

Horgan, Terry, and Mark Timmons. 2000. "Nondescriptivist Cognitivism: Framework for a 
New Metaethic”. Philosophical Papers 29: 121-53.

Horgan, Terry and Mark Timmons. 2006a. "Cognitivist Expressivism”. In Horgan and Timmons, eds., Metaethics after Moore. Oxford: Oxford University Press.

Horgan, Terry and Mark Timmons. 2006b. “Expressivism, Yes! Relativism, No!” In Russ Shafer-Landau, ed., Oxford Studies in Metaethics, Volume 1. Oxford: Oxford University Press.

Horwich, Paul. 1993. "Gibbard's Theory of Norms". Philosophy and Public Affairs 22: 6778.

Jackson, Frank, and Graham Oppy and Michael Smith. 1994. "Minimalism and Truth Aptness". Mind 103: 287-302.

Lenman, James. 2003. "Disciplined Syntacticism and Moral Expressivism". Philosophy and Phenomenological Research 66: 32-57.

Majors, Brad. 2005. "Moral Discourse and Descriptive Properties". Philosophical Quarterly 55: 475-94.

Ridge, Michael. 2006. "Ecumenical Expressivism: Finessing Frege”. Ethics 116: 302-36. Ridge, Michael. 2007. “Ecumenical Expressivism: The Best of Both Worlds?” In Russ Shafer-Landau, ed., Oxford Studies in Metaethics, Volume 2. Oxford: Oxford University Press.

Ridge, Michael. 2009. “The Truth in Ecumenical Expressivism”. In David Sobel and Steven Wall (eds.), Reasons for Action. Cambridge: Cambridge University Press.

Schroeter, Laura, and François Schroeter. 2005. "Is Gibbard a Realist?” Journal of Ethics and Social Philosophy, www.jesp.org, vol. 1, no. 2.

Smith, Michael. 1994a. The Moral Problem. Oxford: Blackwell.

Smith, Michael. 1994b. "Why Expressivists about Value Should Love Minimalism about Truth". Analysis 54: 1-11.

Smith, Michael. 1994c. "Minimalism, Truth-Aptitude and Belief". Analysis 54: 21-6.

Stevenson, Charles L. 1963. Facts and Values. New Haven: Yale University Press.

Streumer, Bart. 2008. “Are there Irreducibly Normative Properties?” Australasian Journal of Philosophy 86: 537-561.

Streumer, Bart. 2011. “Are Normative Properties Descriptive Properties?” Philosophical Studies 154: 325-348.

Streumer, Bart. 2013a. “Can We Believe the Error Theory?” Journal of Philosophy 110: 194- 
212.

Streumer, Bart. 2013b. 'Why There Really Are No Irreducibly Normative Properties'. In

David Bakhurst, Brad Hooker and Margaret Little (eds.), Thinking about Reasons: Essays in Honour of Jonathan Dancy. Oxford: Oxford University Press.

Timmons, Mark. 1999. Morality Without Foundations. Oxford: Oxford University Press. 